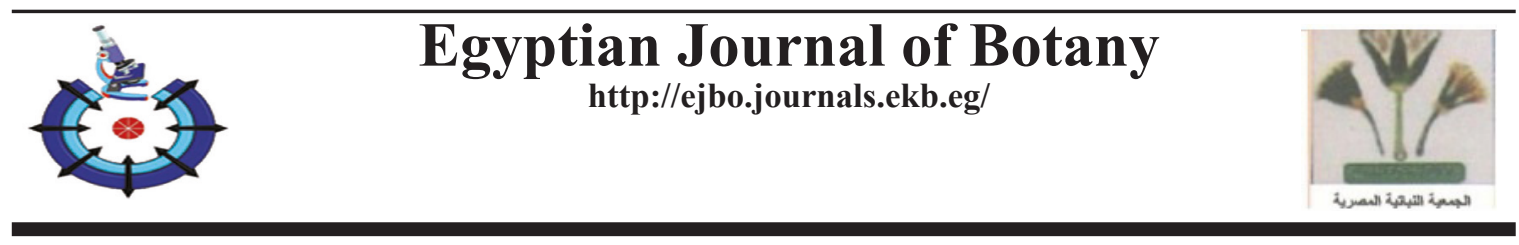

\title{
Screening the Antiviral Activity and Mode of Action of Some Synthetic Fused Heterocyclic Pyrimidines against Tobacco Mosaic Virus (TMV) \& Tobacco Necrosis Virus (TNV) \\ Omar Alfarouk Rabiee \\ Department of Microbiology, Faculty of Science, Ain Shams University, Cairo, Egypt.
}

\begin{abstract}
$\mathbf{P}$ YRIMIDINE and fused heterocyclic pyrimidine derivatives are of great biological interest, especially as antiviral, antitumor and antimicrobial agents. The viruses are one of the most threatening factors for plants resulting in gigantic economic losses. Eight chemical compounds belonging to the fused heterocyclic pyrimidines were screened in order to assay their antiviral activity as well as determining their mechanism of action against two plant viruses TMV and TNV by using the local lesion assay on Datura metel for TMV and Phaseolus vulgaris for TNV. Only two compounds out of eight compounds (1 and 8) showed significant percentage of inhibition for both viruses at concentration $20 \mu \mathrm{g} / \mathrm{ml}$ while the remaining six compounds (2, 3, 4, 5, 7 and 9) showed weak inhibitory activity at same concentration. Mechanism of action studies on both potent compounds revealed that compound number (1) had virucidal activity against both TMV and TNV while compound number (8) seemed to affect the replication process of both viruses.
\end{abstract}

Keywords : Antiviral, Mechanism of action, Pyrimidine derivatives, TMV, TNV.

\section{Introduction}

Plant virus is a type of plant disease, known as "plants cancer". Approximately $15 \%$ of global yield of economically important crops is being reduced every year by different plant diseases (Cerda et al., 2017). Plant viruses account for approximately $30 \%$ of plant diseases (Boualem et al., 2016; Islam et al., 2017). Viruses attacking plants are categorized as the second largest culprits causing huge losses to vegetables, house hold plants, ornamentals and various field crops worldwide, i.e., approximately 60 billion USD in financial terms (Afolabi et al., 2017). Among the most hazardous plant viruses, Tobacco mosaic virus (TMV) and Tobacco necrosis virus (TNV). TMV is a rod shaped positive sensed single stranded (ss) RNA virus (Tobamovirus; Virgaviridae) producing mosaic"-like mottling discoloration symptoms on leaves. It causes massive damage to various crops including 125 plant species such as tobacco, cucumber, pepper and ornamentals (Yang \& Klessig, 1996). TMV is considered as thermo-stable virus tolerating up to $1200^{\circ} \mathrm{F}\left(50^{\circ} \mathrm{C}\right)$ up to 30 minutes (Ashkin \& Dziedzic, 1987). TNV is a polyhedral shaped positive sensed single stranded (ss) RNA virus (Necrovirus; Tombusviridae) producing brown necrotic spots appear near the veins of leaves that may result in defoliation, and also affecting young seedlings that may die. TNV has comparatively broad host range, although not extensively in tobacco, has been transmitted experimentally to many species of plants as well as by soil-borne zoospores

Corresponding author email : omaralfarouk2000@yahoo.com

Received 3/8/2019; Accepted 28/3/ 2020

DOI : $10.21608 /$ ejbo.2020.15594.1346

Edited by: Prof. Dr. Salama A. Ouf, Faculty of Science, Cairo University, Giza 12613, Egypt.

(C)2020 National Information and Documentation Center (NIDOC) 
of the aquatic fungus Olpidium brassicae. In recent review it has been indicated TNV to infect 298 species in 167 genera of 54 families worldwide, particularly in Europe that often causes cucumber necrosis (Edwardson \& Christie, 1997; Šutič et al., 1999). According to International committee of taxonomy of viruses (ICTV), there are 950 different types of plant viruses so far reported on our planet (Brown et al., 2012). Plant virus is an obligate parasite in plant cells. Even in the cell nucleus, nucleic acid (DNA or RNA) replication occurs and coat protein is synthesized in the host cell cytoplasm. Since plants do not have the same immune system as animals, and the virus is absolutely dependent on their hosts, to control plant virus disease and develop plant virus inhibitors appears to be extremely difficult. The development of compounds which delay or inhibit virus multiplication within the plant could form a basis for a more widely applicable method of control. The chemical control method plays an important role in disease prevention because of its simple operation coupled with its economic advantages. As a result, development of efficient, environmentally friendly antiviral agents through chemical synthesis has become the core area of research for eradication of and/or prevention of attack by viruses (Fan et al., 2011). Heterocyclic pyrimidine structures are particularly versatile as it is possible to incorporate functional groups either as substituents or as part of the ring system itself or introduction of an additional ring to the pyrimidines core tends to exert profound influence in conferring novel biological activities in these molecules (Agrofoglio et al., 2003; El-Gazzar et al., 2009). Pyrimidine compounds are widely distributed in nature for example nucleic acid bases (uracil, thymine, and cytosine) are derivatives of pyrimidine, Chlorophyll and heme, thiamine (vitamin B1), riboflavin (vitamin B2), pyridoxol (vitamin B6), nicotinamide (vitamin B3) and ascorbic acid (vitamin C), and also of the twenty aminoacids commonly found in proteins namely histidine, proline and tryptophan are heterocyclic pyrimidine compounds (Lister, 1971 \& Armarego, 1976). Therefore, it is not surprising that a great deal of current research work is concerned with methods of synthesis and properties of heterocyclic compounds. An interest is aroused to the biologically active pyrimidine and fused heterocyclic pyrimidine nucleosides as potent antiviral agents against both human and plant viruses, the literature in this subject is too voluminous to be covered here, however few not all of these studies are mentioned in this paper as examples such as; inhibition of human cytomegalovirus (HCMV) replication by pyrrolo [2, 3-d] pyrimidine derivatives (De clercq, 2004), inhibition of HIV-1 reverse transcriptase by heterocyclic pyrimidine compounds (Fujiwara et al., 2008) and the inhibition of both hepatitis-A virus (HAV) and herpes simplex virus type-1 (HSV1) by some acyclic S-nucleosides of pyrazolo [3,4-d] pyrimidine derivatives (Rashad et al., 2008). In the field of plant virology concerning this issue we can find for example; 6-Azauracil caused a marked reduction in the number and size of local lesions on excised Nicotiana glutinosa leaves or leaf discs inoculated with tobacco mosaic virus or its nucleic acid (Dijkstra \& Van Rensen,1968), the pyrimidine analogues 2-thiouracil, 2-thiouridine, 6-azauracil and 6-azauridine all inhibited the synthesis of turnip yellow mosaic virus (TYMV) in infected Chinese cabbage leaf discs (Ralph \& Wojcik, 1976), Potato viruses have been eliminated in potato meristem culture by using 2,4-dioxohexahydrol,3,5-triazine (Borissensko et al., 1985), and inhibition the multiplication of tobacco mosaic virus and cowpea chlorotic mottle virus in disks from mechanically inoculated leaves by 2-thiopyrimidine and 2,4-dithio pyrimidine (Dawson \& Boyd, 1987). Therefore the main objective of this study was to identify novel heterocyclic pyrimidine compounds.

\section{Materials and Methods}

\section{Chemistry}

The eight chemical compounds under this investigation were kindly synthesized by Prof. Dr. Aymn Elsayed Rashad, Professor of Photochemistry, Photochemistry Department, National Research Centre and Prof. Dr. Klaus Banert Professor of Organic chemistry, Chemnitz University of Technology, Germany.

Compound number one: 1-(6-p-Tolylpyridazin-3-yl)-1, 5-dihydro-pyrazolo[3,4-d]pyrimidin-4-one was prepared by Shamroukh et al. (2005). M.p. $383-4^{\circ}$ C. IR spectrum $\left(\mathrm{KBr}, v, \mathrm{~cm}^{-1}\right): 3102(\mathrm{NH})$, and $1700(\mathrm{CO}) ;{ }^{1} \mathrm{H}$ NMR spectrum (DMSO-d ${ }_{6}, \delta$ ppm): 2.41 (s, 
$3 \mathrm{H}, \mathrm{p}-\mathrm{CH}_{3}$-tolyl), 7.40(d, 2H, J $=7.8 \mathrm{~Hz}, \mathrm{H}_{3}$, $\mathrm{H}_{5}$-tolyl), $8.11\left(\mathrm{~d}, 2 \mathrm{H}, \mathrm{J}=7.5 \mathrm{~Hz}, \mathrm{H}_{2}, \mathrm{H}_{6}-\right.$ tolyl), 8.23 (s, 1H, $\mathrm{H}_{3}$-pyrazole), $8.30(\mathrm{~d}, 1 \mathrm{H}$, $\mathrm{J}=9.3 \mathrm{~Hz}, \mathrm{H}_{5}$-pyridazine $), 8.45-8.48(\mathrm{~m}, 2 \mathrm{H}$, $\mathrm{H}_{4}$-pyridazine and $\mathrm{H}_{6}$-pyrimidine) and 12.51 (brs, $1 \mathrm{H}, \mathrm{NH}$, exchangeable with $\mathrm{D}_{2} \mathrm{O}$ ). MS, $m / z(\%): 304\left(\mathrm{M}^{+}, 100\right)$. Analysis for $\mathrm{C}_{16} \mathrm{H}_{12} \mathrm{~N}_{6} \mathrm{O}$ (304.31): required $\mathrm{C}, 63.15 ; \mathrm{H}, 3.97 ; \mathrm{N}, 27.62$; found $\mathrm{C}, 63.20 ; \mathrm{H}, 4.05 ; \mathrm{N}, 27.48$.

Compound number two: 5-Amino-1(6-p-tolyl-pyridazin-3-yl)-1H-pyrazole4-carboxylic acid amide was prepared by Shamroukh et al. (2005). M.p. 276-8 C. IR spectrum $\left(\mathrm{KBr}, v, \mathrm{~cm}^{-1}\right): 3423-3153\left(2 \mathrm{NH}_{2}\right)$, and $1662(\mathrm{CO}) ;{ }^{1} \mathrm{H}$ NMR spectrum (DMSO-d ${ }_{6}$, $\delta \mathrm{ppm}$ ): 2.40 (s, 3H, p-CH - -tolyl), 7.10 (brs, $2 \mathrm{H}, \mathrm{NH}_{2}$, exchangeable with $\left.\mathrm{D}_{2} \mathrm{O}\right), 7.39$ (d, $2 \mathrm{H}, \mathrm{J}=7.8 \mathrm{~Hz}, \mathrm{H}_{3}, \mathrm{H}_{5}$-tolyl), 7.63 (s, 2H, $\mathrm{NH}_{2}$, exchangeable with $\left.\mathrm{D}_{2} \mathrm{O}\right), 8.05-8.07(\mathrm{~m}, 3 \mathrm{H}$, $\mathrm{H}_{2}, \mathrm{H}_{6}$-tolyl and $\mathrm{H}_{3}$-pyrazole $), 8.17(\mathrm{~d}, 1 \mathrm{H}, \mathrm{J}=$ $9.3 \mathrm{~Hz}, \mathrm{H}_{5}$-pyridazine), $8.40(\mathrm{~d}, 1 \mathrm{H}, \mathrm{J}=9.3 \mathrm{~Hz}$, $\mathrm{H}_{4}$-pyridazine); MS, m/z (\%): $294\left(\mathrm{M}^{+}, 100\right)$. Analysis for $\mathrm{C}_{15} \mathrm{H}_{14} \mathrm{~N}_{6} \mathrm{O}$ (294.32): required $\mathrm{C}$, 61.22; H, 4.79; N, 28.55; found C, 61.12; H, 4.58; N, 28.75.

Compound number three: 2 - Aminonaphtho $[2,1-b]$ thiophene-1 carbonitrile was prepared by Rashad et al. (2010). M.p. 215-217 ${ }^{\circ} \mathrm{C}$. IR (KBr, n, $\mathrm{cm}^{-}$ $\left.{ }^{1}\right)$ : 3390-3250 $\left(\mathrm{NH}_{2}\right), 2218(\mathrm{C} \equiv \mathrm{N}) .{ }^{1} \mathrm{H}$ NMR (DMSO-d,$\delta$ ppm): 5.29 (brs, $2 \mathrm{H}, \mathrm{NH}_{2}, \mathrm{D}_{2} \mathrm{O}$, exchangeable), 7.52-7.62 (m, 4H, Ar-H), 8.27 $(\mathrm{d}, 1 \mathrm{H}, \mathrm{J}=4.8 \mathrm{~Hz}, \operatorname{Ar}-\mathrm{H}), 8.99(\mathrm{~d}, 1 \mathrm{H}, \mathrm{J}=$ $5.2 \mathrm{~Hz}, \mathrm{Ar}-\mathrm{H}) .{ }^{13} \mathrm{C}$ NMR (DMSO-d,$\delta \mathrm{ppm}$ ): $119.32(\mathrm{C} \equiv \mathrm{N})$ 127-145 ( $\mathrm{sp}^{2}$ carbon atoms). MS m/z (\%): $224\left(\mathrm{M}^{+}, 59 \%\right)$. Anal. calcd. for $\mathrm{C}_{13} \mathrm{H}_{8} \mathrm{~N}_{2} \mathrm{~S}$ (224.29): C 69.62, H 3.60, N 12.49. Found: C 69.49, H 3.51, N 21.64.

Compound number four: 2-Aminoindeno [2,1-b]thiophene-3-carbonitrile was prepared by Hegab et al. (2007). IR; $v$ 2280, 2200 $\left(\mathrm{NH}_{2}\right), 2210$ (CN). ${ }^{1} \mathrm{H}$ NMR (DMSO-d $6, \delta$ ppm): $3.75\left(\mathrm{~s}, 2 \mathrm{H}, \mathrm{CH}_{2}\right), 4.80\left(\mathrm{~s}, 2 \mathrm{H}, \mathrm{NH}_{2}, \mathrm{D}_{2} \mathrm{O}\right.$ exchangeable), 7.20-7.60 (m, 3H, Ar-H), 7.75 (d, J = 6.00 Hz, 1H, Ar-H). MS: $m / z 212\left(\mathrm{M}^{+}\right.$, 100), 196 (1.71), 184 (4.20).

$\begin{array}{lr}\text { Compound } & \text { number } \\ 5,6,10 \text {-Trihydronaphtho[ }\left[1^{\prime},\right. & \left.2^{\prime}: 4,5\right] \\ \text { thieno[2,3-d]pyrimidin-11-one } & \text { was prepared } \\ \text { by Rashad et al. (2005). M.p. } 268-270^{\circ} \mathrm{C} \text {. }\end{array}$

Calcd. for $\mathrm{C}_{14} \mathrm{H}_{10} \mathrm{~N}_{2} \mathrm{OS}$ (254.31): C, 66.12; H, 3.96; N, 11.02; S, 12.61. Found: C, 66.20; H, $3.80 ; \mathrm{N}, 10.83 ; \mathrm{S}, 12.40$. IR (KBr): $v_{\mathrm{NH}} \mathrm{cm}^{-1}$ $3100, v_{\text {co }} 1625 \mathrm{~cm}^{-1}$. ${ }^{1} \mathrm{H}$ NMR (DMSO-d,$\delta$ ppm): 2.80-3.10 (m, 4H, 2CH $), 7.20-7.50(\mathrm{~m}$, $3 \mathrm{H}, \operatorname{Ar}-\mathrm{H}), 8.10\left(\mathrm{~s}, 1 \mathrm{H}, \mathrm{C}_{9}-\mathrm{H}\right), 8.40(\mathrm{~d}, \mathrm{~J}=$ $10.45 \mathrm{~Hz}, 1 \mathrm{H}, \mathrm{Ar}-\mathrm{H}), 12.15$ (s, 1H, NH, D $\mathrm{O}$ exchangeable). MS, $m / z(\%): 254\left(\mathrm{M}^{+}, 100\right)$, 226 (5.67).

Compound number seven: 11-(2-Methoxyethylsulfanyl) $\quad-5,6 \quad$-dihydronaphtho[1, 2:4,5]thieno[2,3-d] pyrimidine was prepared by Rashad \& Ali (2006). M.p. $102-104^{\circ} \mathrm{C}$; ${ }^{1} \mathrm{H}-\mathrm{NMR}\left(\mathrm{CDCl}_{3}, \delta \mathrm{ppm}\right): 2.86-2.97(\mathrm{~m}, 4 \mathrm{H}$, $\left.2 \mathrm{CH}_{2}\right), 3.37\left(\mathrm{~s}, 3 \mathrm{H}, \mathrm{OCH}_{3}\right), 3.54(\mathrm{t}, \mathrm{J}=7 \mathrm{~Hz}, 2 \mathrm{H}$, $\left.\mathrm{CH}_{2} \mathrm{O}\right), 3.69\left(\mathrm{t}, \mathrm{J}=7.5 \mathrm{~Hz}, 2 \mathrm{H}, \mathrm{CH}_{2} \mathrm{~N}\right), 7.20$ 7.40 (m, 3H, Ar-H), 7.80 (d, J=8 Hz, 1H, Ar-H), $8.25\left(\mathrm{~s}, 1 \mathrm{H}, \mathrm{C}_{9}-\mathrm{H}\right) ;{ }^{13} \mathrm{C}-\mathrm{NMR}\left(\mathrm{CDCl}_{3}, \delta \mathrm{ppm}\right)$ : 25.56 (C-5), $29.78(\mathrm{C}-6), 29.78\left(\mathrm{OCH}_{3}\right), 58.89$ $\left(\mathrm{CH}_{2} \mathrm{O}\right), 71.21\left(\mathrm{CH}_{2} \mathrm{~N}\right), 125.94-128.02(\mathrm{Ar}-\mathrm{C})$, 130.97 (C-11a), 135.94 (C-11b), 141.24 (C6a), 151.34 (C-7a), 162.98 (C-9), 166.22 (C11); calculated for $\mathrm{C}_{17} \mathrm{H}_{16} \mathrm{~N}_{2} \mathrm{OS}_{2}$ (328.46): $\mathrm{C}$, 62.17; H, 4.91; N, 8.53; S, 19.52. Found: C, $62.10 ; \mathrm{H}, 4.85 ; \mathrm{N}, 8.63 ; \mathrm{S}, 19.60$.

Compound number eight: 1,10-Dihydroindeno[1', 2`:4, 5] thieno [2,3d] $[1,2,4]$ triazolo [4,3-a] pyrimidin-5-one was prepared by Rashad et al. (2010). M.p. 250-252 ${ }^{\circ} \mathrm{C}$. IR spectrum (KBr, v, $\left.\mathrm{cm}^{-1}\right): 3334$ (NH), 1643 (CO); ${ }^{1} \mathrm{H}$ NMR spectrum $\left(\mathrm{CDCl}_{3}\right.$, $\delta \mathrm{ppm}): 3.36\left(\mathrm{~s}, 2 \mathrm{H}, \mathrm{CH}_{2}\right), 6.90\left(\mathrm{~s}, 1 \mathrm{H}, \mathrm{C}_{3}-\mathrm{H}\right)$, 7.24-7.54 (m, 4H, Ar-H), 9.85 (s, 1H, NH, D, O exchangeable); ${ }^{13} \mathrm{C}$ NMR (DMSO-d ${ }_{6}, \delta \mathrm{ppm}$ ): 36.58 (C-10), 119.45-164.32 (Ar-C), 170.50 $(\mathrm{C}=\mathrm{O})$. MS, $m / z(\%): 280\left(\mathrm{M}^{+}, 100\right)$. Anal. calcd. for $\mathrm{C}_{14} \mathrm{H}_{8} \mathrm{~N}_{4} \mathrm{OS}$ : C, 59.99; $\mathrm{H}, 2.88 ; \mathrm{N}$, 19.99; S, 11.44. Found: C, 60.03; H, 2.95; N, 19.89; S, 11.38.

Compound number nine: 11-Amino-5,6dihydronaphtho $\left[1^{\prime}, 2^{\prime}: 4,5\right]$ thieno $[2,3-\mathrm{d}]$ pyrimidine- $9(8 \mathrm{H})$ - thione was prepared by Abdel-Megeid et al. (1998). M.p. $150-2^{\circ} \mathrm{C}$; Calcd. for $\mathrm{C}_{14} \mathrm{H}_{11} \mathrm{~N}_{3} \mathrm{~S}_{2}$ (286.78): C, 63.04; H, $3.85 ; \mathrm{N}, 9.80 ; \mathrm{S}, 11.20$. Found: C, 63.80; H, $3.83 ; \mathrm{N}, 9.40 ; \mathrm{S}, 1120$. IR (KBr, $\left.v, \mathrm{~cm}^{-1}\right): 1055$ $(\mathrm{C}-\mathrm{Cl}) ;{ }^{1} \mathrm{H}$ NMR (DMSO-d $6, \delta$ ppm): 2.7 (s, $\left.3 \mathrm{H}, \mathrm{CH}_{3}\right), 2.8-3.0\left(\mathrm{~m}, 4 \mathrm{H}, \mathrm{CH}_{2} \mathrm{CH}_{2}\right), 7.2-7.4(\mathrm{~m}$, $3 \mathrm{H}, \mathrm{Ar}-\mathrm{H})$; MS, $m / z(\%): 288\left(\mathrm{M}^{+},{ }^{37} \mathrm{Cl}, 38.4\right)$, $286\left(\mathrm{M}^{+},{ }^{35} \mathrm{Cl}, 100\right), 271$ (1.47), 251 (7.25),249 (9.28), 209 (9.51), 164 (7.65), 139 (4.86). 


\begin{tabular}{|c|c|c|c|}
\hline $\begin{array}{l}\text { Cpd. } \\
\text { No. }\end{array}$ & Name & $\begin{array}{l}\text { Chemical } \\
\text { formula }\end{array}$ & Chemical structure \\
\hline 1 & $\begin{array}{l}\text { 1-(6-p-Tolyl-pyridazin-3-yl)-1,5-dihydro- } \\
\text { pyrazolo[3,4-d]-pyrimidine-4-one }\end{array}$ & $\mathrm{C}_{16} \mathrm{H}_{12} \mathrm{~N}_{6} \mathrm{O}$ & \\
\hline 2 & $\begin{array}{l}\text { 5-Amino-1-(6-p-tolyl-pyridazin-3-yl)-1H- } \\
\text { pyrazole-4-carboxylic acid amide }\end{array}$ & $\mathrm{C}_{15} \mathrm{H}_{14} \mathrm{~N}_{6} \mathrm{O}$ & \\
\hline 3 & $\begin{array}{l}\text { 2-Aminonaphtho[2,1-b]thiophene-1- } \\
\text { carbonitrile }\end{array}$ & $\mathrm{C}_{13} \mathrm{H}_{8} \mathrm{~N}_{2} \mathrm{~S}$ & \\
\hline 4 & $\begin{array}{l}\text { 2-Aminoindeno[2,1-b] thiophene-3- } \\
\text { carbonitrile }\end{array}$ & $\mathrm{C}_{12} \mathrm{H}_{8} \mathrm{~N}_{2} \mathrm{~S}$ & \\
\hline 5 & $\begin{array}{l}\text { 5,6,10-Trihydronaphtho }\left[1^{\prime}, 2^{\prime}: 4,5\right] \\
\text { thieno }[2,3-d] \text { pyrimidin-11-one }\end{array}$ & $\mathrm{C}_{14} \mathrm{H}_{10} \mathrm{~N}_{2} \mathrm{OS}$ & \\
\hline 7 & $\begin{array}{l}\text { 11-(2-Methoxy-ethylsulfanyl)-5,6- } \\
\text { dihydronaphtho[1,2:4,5] thieno[2,3-d] } \\
\text { pyrimidine }\end{array}$ & $\mathrm{C}_{17} \mathrm{H}_{16} \mathrm{~N}_{2} \mathrm{OS}_{2}$ & \\
\hline 8 & $\begin{array}{l}\text { 1,10-Dihydroindeno[ }\left[1^{\prime}, 2^{\prime}: 4,5\right] \text { thieno }[2,3-\mathrm{d}] \\
{[1,2,4] \text { triazolo[4,3-a]pyrimidine-5-one }}\end{array}$ & $\mathrm{C}_{14} \mathrm{H}_{8} \mathrm{~N}_{4} \mathrm{OS}$ & \\
\hline 9 & $\begin{array}{l}\text { 11-Amino-5,6-dihydronaphtho }\left[1^{\prime}, 2^{\prime}: 4,5\right] \\
\text { thieno[2,3-d]pyrimidine- } 9(8 \mathrm{H}) \text {-thione }\end{array}$ & $\mathrm{C}_{14} \mathrm{H}_{11} \mathrm{~N}_{3} \mathrm{~S}_{2}$ & \\
\hline
\end{tabular}

Egypt. J. Bot. 60 , No.2 (2020) 


\section{Plant infectivity assay materials}

Assay host plants

Phaseolus vulgaris seeds were obtained from seed bank of botanical garden, Faculty of Science, Ain Shams University and were used in local lesion assay for TNV while (Datura metel) seeds were kindly provided by Prof. Dr. Badawe Abd Elsalam Osman, Professor of Virology, Faculty of Agriculture, Ain Shams University and were used in local lesion assay for TMV.

\section{Plant viruses}

Tobacco Necrosis Virus was obtained from Microbiology Department, Faculty of Science, Ain shams university. Tobacco Mosaic Virus was kindly provided by Prof. Dr. Badawe Abd Elsalam Osman, Professor of Virology, Faculty of Agriculture, Ain Shams University.

Preparation of synthetic compounds for bioassay

Tested compounds were dissolved as $10 \mathrm{mg}$ each in $1 \mathrm{~mL}$ of $10 \%$ Dimethyl Sulfoxide (DMSO) in deionized water $(900 \mu \mathrm{L}$ de-ionized water and $100 \mu \mathrm{L}$ DMSO).

\section{Growth of assay host plants}

Seeds of each host plant were sown in $15 \mathrm{~cm}$ plastic pots containing mixture of clay and sand. Five plants were grown per pot, in the Green house, Virology Unit, Ain-Shams University. Leaves were ready for inoculation after 15-20 days from planting. Only healthy plants with good appearance were used for infectivity assays.

\section{Preparation of virus inocula}

The infected leaves with virus were stored at $-20^{\circ} \mathrm{C}$ and used as a source of virus. Frozen infected leaves were ground with distilled water $(1: 2 \mathrm{w} / \mathrm{v})$ using a pestle and mortar. The bulk of leaf debris was removed by squeezing through four layers of muslin. Each extract was centrifuged at $4,000 \mathrm{~g}$ for $15 \mathrm{~min}$ then the supernatant was kept at $-20^{\circ} \mathrm{C}$ overnight to precipitate any proteinaceous virus inhibitor presented in leaf sap. The supernatant was further clarified by centrifugation at $3,000 \mathrm{~g}$ for $15 \mathrm{~min}$. Aliquots of clarified virus inocula were stored in glass vials at $-20^{\circ} \mathrm{C}$. When required, clarified virus inocula were thawed and diluted with distilled water or phosphate buffer $(\mathrm{pH} 7)$ to give a suitable number of discrete local lesions on test plants (Velazhahan \& Narayanasamy, 1991).

\section{Antiviral screening of chemical compounds}

The inhibitory activity of chemical compounds was examined by mixing an equal volume of compound with virus inocula $(1: 1 \mathrm{v} / \mathrm{v})$ and then inoculated onto leaves of test plants. Before mechanical inoculation, the plants were dusted with 600-mesh carborandum as an abrasive, the inoculation was made by dipping the forefinger in inoculums and rubbing over the upper surface of the leaf. In control plants, the leaves were inoculated with virus inocula mixed with an equal volume of water instead of compound (act as a positive control),while in another set the leaves were inoculated only with the same volume of compound (act as a negative control) in order to test the toxicity of these compounds on the plants. The development of local lesions were recorded 3-5 days after inoculation. The percentage of inhibition was calculated according to Smookler's formula (1971):

$$
100-(\mathrm{A} / \mathrm{B} \times 100)
$$

where (A) is the number of local lesions formed on treated leaves while $(\mathrm{B})$ is the number of local lesions formed on control "untreated" leaves.

\section{Studying the mechanism of action of chemical compounds}

Virus inhibited mechanism was studied for the Chemical compounds in three categories:

a) Pre-inoculation Treatment (Modified from Zhang et al., 1995): The compound was sprayed firstly on host plant leaves $24 \mathrm{hrs}$ before inoculation with virus. This method is used to detect whether the compound has affect the adsorption process (act as virus inhibitor) or not.

b) Post-inoculation Treatment (Modified from Amoros et al., 1994): In another set of plants, the virus was inoculated first followed by spraying of compound at $24 \mathrm{hrs}$ after inoculation. This method is used to detect whether the compound affect the virus replication (act as virus inhibitor) or not.

c) Simultaneous-inoculation Treatment (Modified from Schuhmacher et al., 2003): The mixture of virus and compound was incubated at room temperature for $1 \mathrm{hr}$ then inoculated into host plant. This method is used to detect whether the compound has virucidal activity (act as virus inactivator) or not. 


\section{Results}

In this work a preliminary screening has been done to estimate the antiviral effect(s) of eight synthetic chemical compounds belonging to the fused heterocyclic pyrimidines group against two plant viruses (TNV) and (TMV). It is well known that an interest is aroused in many new researches about the biologically active fused heterocyclic pyrimidine nucleosides and its derivatives as potent antiviral agents. From this screening, effective and promising compounds against plant viruses have been determined as well as their mechanism of action.

\section{Cytotoxicity assay of the chemical compounds}

Plant cytotoxicity test was carried firstly before screening the antiviral activity of these compounds to be sure that they were safe on plant cells. Healthy test plants (act as negative controls) were sprayed only with each compound at concentrations 10 and $20 \mu \mathrm{g} / \mathrm{mL}$ then observing the appearance of any abnormal morphological changes in shape or color such as chlorosis, mottling, necrosis, wilting, and curling that occurs to the test plants for about three days after inoculation. The results of cytotoxicity test indicated that all tested concentrations for each compound were safe on test plants and didn't show any signs of toxicity on host cells.

\section{Antiviral screening of the chemical compounds}

Local lesion assay is the most widely accepted method for determining the $\%$ inhibition of plant virus as a result of being subjected to a given material. The results of antiviral screening in (Table 1) showed that two out of eight compounds showed high percentage of inhibition at concentration $20 \mu \mathrm{g} / \mathrm{mL}$ for both viruses. These compounds were number 1 and 8 giving ( 82.6 for TNV / 85.4 for TMV) and (74.6 for TNV / 79.6 for TMV) \% of inhibition, respectively. This result revealed also that the inhibitory activity of compound number 1 was higher than that for compound number eight for both concentrations and for both viruses. The remaining six compounds showed weak inhibitory activity at same concentration. These compounds were number 2, 3, 4, 5, 7 and 9. Generally, at conc. $10 \mu \mathrm{g} / \mathrm{mL}$ the percentage inhibition was slightly reduced for most tested compounds for both viruses comparing with $20 \mu \mathrm{g} / \mathrm{mL}$ but this reduction was non significance. The local lesions of TNV and that of TMV that were formed on their host plants were clearly showed in Fig.1 and Fig. 2, respectively.

TABLE 1. Screening for antiviral activity of pyrimidine compounds against TNV \& TMV.

\begin{tabular}{|c|c|c|c|c|c|}
\hline \multirow{3}{*}{ 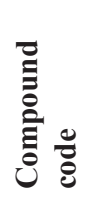 } & \multirow{3}{*}{ 苞 } & \multicolumn{4}{|c|}{ Plant infectivity assay } \\
\hline & & \multicolumn{2}{|c|}{ Anti-TNV on Phaseolus vulgaris } & \multicolumn{2}{|c|}{ Anti-TMV on Datura metel } \\
\hline & & $\begin{array}{c}\text { "Mean No. } \\
\text { of L.L.'. }\end{array}$ & $\begin{array}{l}\% \text { Virus } \\
\text { inhibition }\end{array}$ & $\begin{array}{c}\text { "Mean No. } \\
\text { of L.Ls. }\end{array}$ & $\begin{array}{c}\text { \% Virus } \\
\text { inhibition }\end{array}$ \\
\hline \multirow{2}{*}{1} & 10 & 14.3 & 79.6 & 8.2 & 82.1 \\
\hline & 20 & 12.2 & 82.6 & 6.7 & 85.4 \\
\hline \multirow{2}{*}{2} & 10 & 67.4 & 3.9 & 25.3 & 44.6 \\
\hline & 20 & 65.7 & 6.4 & 24.5 & 46.4 \\
\hline \multirow{2}{*}{3} & 10 & 42.5 & 39.5 & 24.8 & 45.7 \\
\hline & 20 & 39.7 & 43.4 & 24.1 & 47.3 \\
\hline \multirow{2}{*}{4} & 10 & 46.3 & 34.1 & 28.3 & 38.1 \\
\hline & 20 & 45.6 & 35.0 & 28.0 & 38.7 \\
\hline \multirow{2}{*}{5} & 10 & 47.2 & 32.7 & 30.2 & 33.9 \\
\hline & 20 & 46.6 & 33.6 & 29.7 & 35.0 \\
\hline \multirow{2}{*}{7} & 10 & 51.6 & 26.5 & 26.2 & 42.6 \\
\hline & 20 & 50.2 & 28.5 & 24.7 & 45.9 \\
\hline \multirow{2}{*}{8} & 10 & 22.1 & 68.5 & 10.6 & 76.8 \\
\hline & 20 & 17.8 & 74.6 & 9.3 & 79.6 \\
\hline \multirow{2}{*}{9} & 10 & 38.9 & 44.6 & 31.2 & 31.7 \\
\hline & 20 & 37.4 & 46.7 & 29.8 & 34.8 \\
\hline \multicolumn{2}{|c|}{ Positive control } & 70.2 & 0 & 45.7 & 0 \\
\hline
\end{tabular}

(*) : Total number of local lesions divided by 10 primary leaves.

Egypt. J. Bot. 60 , No.2 (2020) 

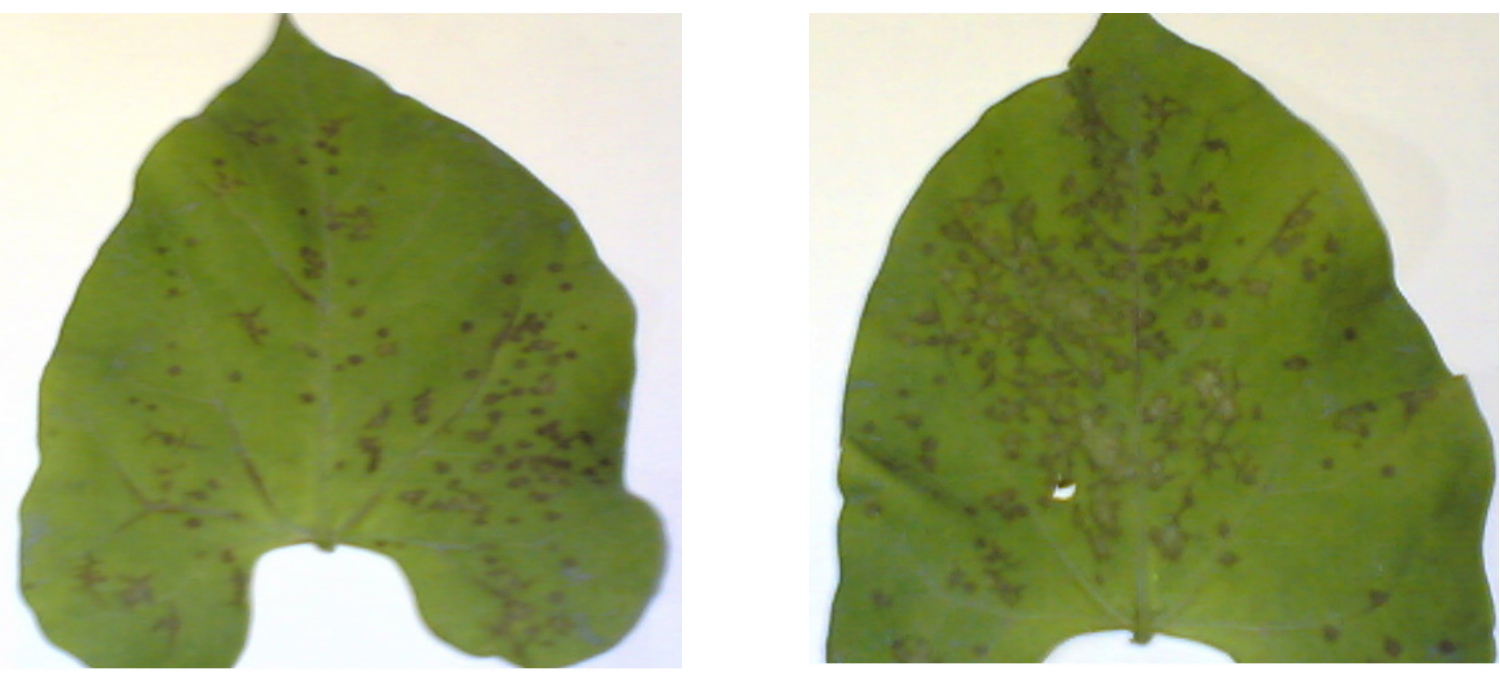

Fig. 1. Necrotic local lesions formation on Phaseolus vulgaris leaf after inoculation with TNV.
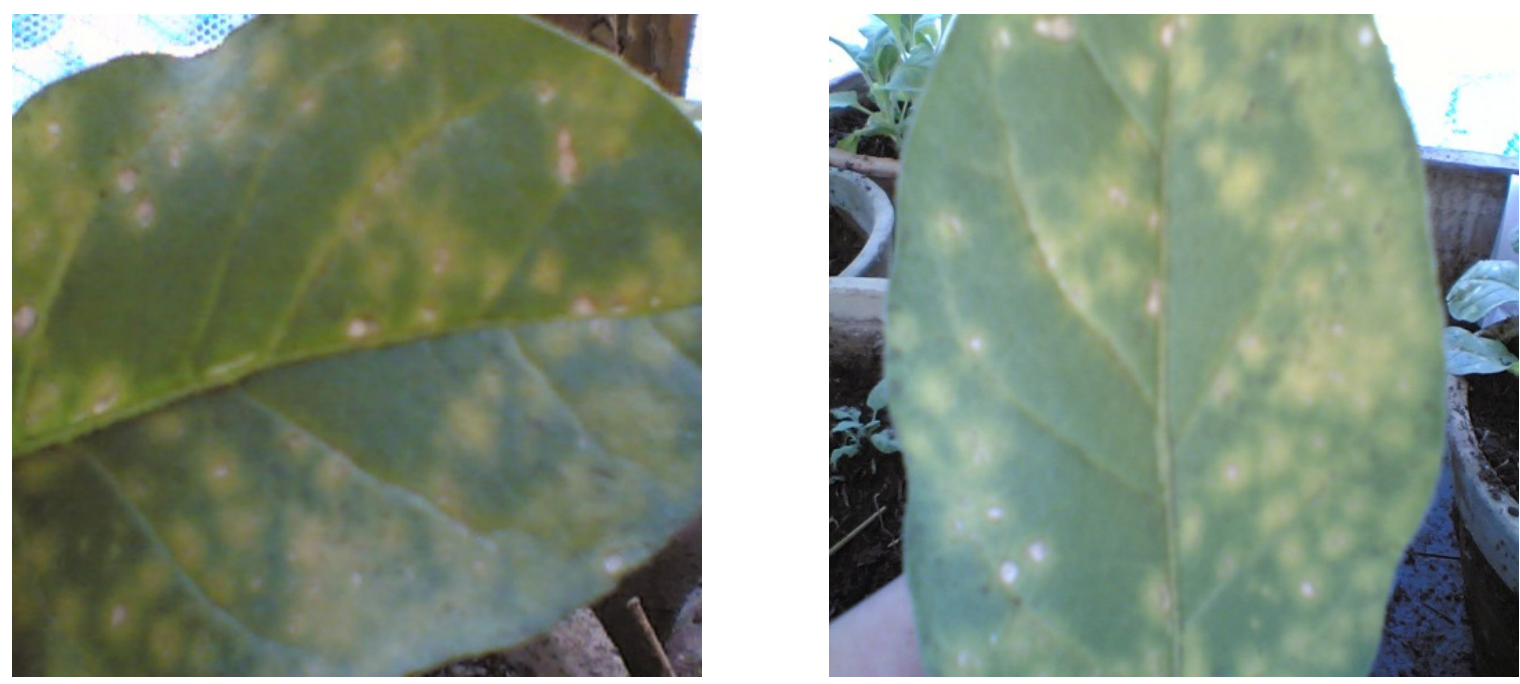

Fig. 2. Chlorotic local lesions formation on Datura metel leaf after inoculation with TMV.

Another observation from the data shown in Table 1 was that; TMV was more affected by the inhibitory activity of chemical compounds than that for TNV for most tested compounds and this may owes to the difference in morphology of each virus; where the rod shaped TMV has a larger surface area subjected to the compounds in comparison with the polyhedral shaped TNV which has compacted and small surface area subjected to the compound.

\section{Studying the mechanism of action of chemical compounds}

The potency of antiviral activity of the two selected synthetic compounds against TNV and TMV leads us to study further details concerning their mechanism of action. Accordingly, we have to answer if these compounds have virucidal activity or they affect the adsorption process or they may inhibit virus replication in some way. Plant virus inhibited mechanism was studied for the most potent chemical compounds (No.1 $\&$ No.8) in three categories; Pre-inoculation treatment (Table 2), Post-inoculation treatment (Table 3) and Simultaneous-inoculation treatment (Table 4).

The results in Table 2 revealed that preinoculation treatment of test plants with both compounds was not effective at all against both viruses (gave the weakest \% of virus inhibition). This suggested that these compounds had no any effect on the attachment process of the virus to the infective sites (i. e., can't prevent the entry of 
virus into plant cells). From the results shown in Table 3, it was clear that compound (No.1) had no effect on the replication process of both viruses inside the plants (gave no significant \% of virus inhibition) $27.9 \%$ for TNV and 44.6 $\%$ for TMV. However, only compound (No. 8) showed strong $\%$ of virus inhibition for both viruses, it gave $77.5 \%$ for TNV and $80.6 \%$ for TMV. The inhibition in replication showed by compound (No. 8) might be either due to it may acts as a nucleoside analogue that interfere in the replicative cycle of the virus for example, by being incorporated in place of the natural nucleoside or by inactivation of the viral RNA polymerase complex in some way affecting transcription and replication processes of viral genome. During evaluation the virucidal effect of both compounds by subjecting virus to the compounds directly. The results in Table 4 showed that only compound (No.1) had strong virucidal effect giving $81.7 \%$ inhibition for TNV and $86.2 \%$ for TMV. On the other hand, compound (No.8) showed a very weak effect on both viruses giving 33\% for TNV and 34.3\% for TMV. This may be due to the direct binding between the virus particles and compound (No.1) results in the formation of virus-inhibitor complex (i. e., the chemical configuration of this compound contains certain heterocyclic moieties which may alter virus capsid proteins) so the effect of compound (No.1) here appears to be on the virus itself. In this case, it was described as virus inactivator (virucidal). The summary on the effect of different treatments of $P$. vulgaris and $D$. metel with compounds no. (1) and (8) on the \% of virus inhibition was clearly showed in Fig. 3.

TABLE 2. Effect of pre-treatment of leaves of Phaseolus vulgaris \& Datura metel with compounds No. (1) \& No. (8) on subsequent local lesions production by TNV \& TMV, respectively.

\begin{tabular}{lcccc}
\hline \multirow{2}{*}{$\begin{array}{l}\text { Compound } \\
\text { conc. used }\end{array}$} & \multicolumn{2}{c}{ TNV $/$} & \multicolumn{2}{c}{ TMV } \\
\cline { 2 - 5 } & $\begin{array}{c}\text { *Mean No. } \\
\text { of L.L. }\end{array}$ & $\begin{array}{c}\text { \% Virus } \\
\text { inhibition }\end{array}$ & $\begin{array}{c}\text { Mean No. } \\
\text { of L.L. }\end{array}$ & $\begin{array}{c}\text { \% Virus } \\
\text { inhibition }\end{array}$ \\
\hline $1 \rightarrow(20 \mu \mathrm{g} / \mathrm{mL})$ & 59.3 & 13.3 & 39.6 & 7.5 \\
$8 \rightarrow(20 \mu \mathrm{g} / \mathrm{mL})$ & 65.5 & 4.2 & 40.3 & 5.8 \\
Positive control & 68.4 & 0 & 42.8 & 0 \\
\hline
\end{tabular}

TABLE 3. Effect of post-treatment of leaves of Phaseolus vulgaris \& Datura metel with compounds No. (1) \& No. (8) on subsequent local lesions production by TNV \& TMV, respectively.

\begin{tabular}{|c|c|c|c|c|}
\hline \multirow{2}{*}{$\begin{array}{l}\text { Compound } \\
\text { conc. used }\end{array}$} & \multicolumn{2}{|c|}{ TNV } & \multicolumn{2}{|c|}{ TMV } \\
\hline & $\begin{array}{c}\text { *Mean No. } \\
\text { of L.L. }\end{array}$ & $\begin{array}{c}\% \text { Virus } \\
\text { inhibition }\end{array}$ & $\begin{array}{c}\text { Mean No. } \\
\text { of L.L. }\end{array}$ & $\begin{array}{l}\text { \% Virus } \\
\text { inhibition }\end{array}$ \\
\hline $1 \rightarrow(20 \mu \mathrm{g} / \mathrm{mL})$ & 49.3 & 27.9 & 23.7 & 44.6 \\
\hline $8 \rightarrow(20 \mu \mathrm{g} / \mathrm{mL})$ & 15.4 & 77.5 & 8.3 & 80.6 \\
\hline Positive Control & 68.4 & 0 & 42.8 & 0 \\
\hline
\end{tabular}

TABLE 4. Effect of simultaneous-treatment of leaves of Phaseolus vulgaris \& Datura metel with compounds No. (1) \& No. (8) on subsequent local lesions production by TNV \& TMV, respectively.

\begin{tabular}{|c|c|c|c|c|}
\hline $8 \rightarrow(20 \mu \mathrm{g} / \mathrm{mL})$ & 45.8 & 33.0 & 28.1 & 34.3 \\
\hline Positive Control & 68.4 & 0 & 42.8 & 0 \\
\hline
\end{tabular}

(*) : Total number of local lesions divided by 10 primary leaves.

Egypt. J. Bot. 60 , No.2 (2020) 


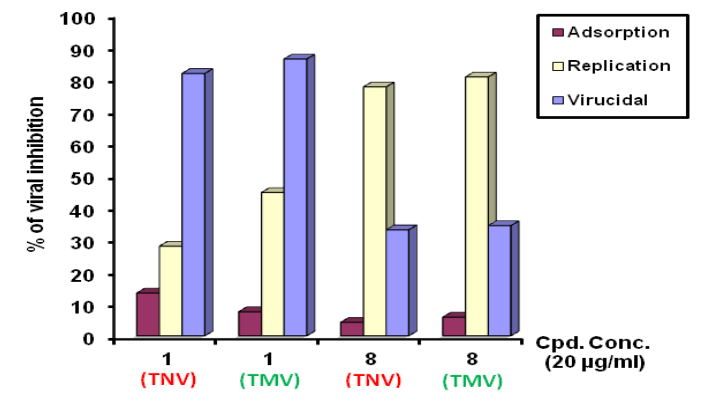

Fig. 3. Effect of different treatments of $P$. vulgaris \& D. metel with compounds no. (1) \& (8) on the $\%$ of virus inhibition.

\section{Discussion}

The objective of this study was concerned with identifying for any novel anti-TNV and antiTMV inhibitors using heterocyclic pyrimidine compounds since an interest is aroused on the biologically active pyrimidine and fused heterocyclic pyrimidine nucleosides as potent antiviral agents. The result obtained from plant cytotoxicity test agreed with some previous work on these types of chemical compounds in several searches in that field for example, Matthews (1953) found that in concentrations up to c. $0.005 \mathrm{M}$ the guanine analogue, 5-amino-7hydroxy-1-v-triazolo (D) pyrimidine (guanazolo) usually caused negligible plant damage, but at higher concentrations produced a slight yellowing and distortion in the younger leaves with general stunting if treatments were prolonged, also no cytotoxicity was recorded when determine the effect of both purine and pyrimidine analogues on the infectivity of Sunflower mosaic virus in vitro and in vivo by Gupta \& Roy (1981), also the cytotoxicity test using MTT assay (Mossman, 1983) for some novel fused thiophene and thienopyrimidine derivatives showed that they were safe on MDCK cells in vitro (Rashad et al., 2010; Alfarouk et al., 2013).

Concerning the antiviral activity of these chemical compounds, several reports have been demonstrated the effectiveness of synthetic fused heterocyclic pyrimidine compounds in inhibiting plant as well as human viruses. For examples, the guanine analogue, 8-azaguanine, had a marked inhibitory effect on lucerne mosaic and cucumber mosaic viruses but had much less effect on disease development with tobacco mosaic virus by Matthews (1953), the inhibitory action of halogenated pyrimidines such as 5-fluoruoridine, and 2-thio-5-fluorouracil on the formation of TMV in isolated leaf disks of Turkish tobacco plants by Staehelin \& Gordon (1960), the effectiveness of both purine and pyrimidine analogues on the infectivity of Sunflower mosaic virus in vitro and in vivo by Gupta \& Roy (1981), the antiviral activity of novel thiourea containing chiral phosphonate on Tobacco Mosaic Virus by Fan et al. (2011), Wenneng et al. (2015) found that the newly synthesized 2-substituted methylthio5-(4-amino-2-methylpyrimidin-5-yl-)-1,3,4oxadiazole derivatives exhibited a potent antiviral against TMV in vivo, a series of pyrazolo[3,4- $d]$ pyrimidine derivatives containing a schiff base moiety exhibited significant activity against TMV by Wang et al. (2018), the 4-[(1,2-dihydro-2-oxo$3 \mathrm{H}$-indol-3-ylidene)amino]- $\mathrm{N}$-(4,6-dimethyl2-pyrimidin-2-yl) benzene-sulphonamide and its derivatives showed antiviral potencies $(90 \%$ inhibition) against influenza A (H1N1, H3N2, and $\mathrm{H} 5 \mathrm{~N} 1$ ) and $\mathrm{B}$ viruses in MDCK cell culture by Selvam et al. (2006) and the anti-HSV-1 activity of some new synthesized substituted pyrimidine, thiopyrimidine and thiazolopyrimidine derivatives by Mohamed et al. (2010).

During studying the effect of both compounds (cpd. no. 1 \& cpd. no.8) on the adsorption process of (TNV) and (TMV) viruses conversely data from several researches were obtained for example; Matthews (1953) found that the guanine analogue, 5-amino-7-hydroxy-1-v-triazolo (D) pyrimidine (guanazolo) was more effective in reducing the number of local lesions and delayed or inhibited systemic spread of lucerne mosaic virus on the leaves of tobacco or Nicotiana glutinosa plants when applied (sprayed) before virus inoculation, also similar results were obtained by Gupta \& Roy (1981) when sprayed some purine and pyrimidine analogues on test plant leaves an hour before sunflower mosaic virus inoculation giving $89.04 \%$ inhibition. However similar results from many reports were obtained during study the mechanism of action of some new synthesized substituted pyrimidines against some plant viruses concerning their effect on virus replication as well as virus inactivator for example; Matthews (1953) found that when sprayed on the leaves of tobacco plants inoculated with tobacco mosaic virus 8-azaguaninecaused a delay in the production of virus, and a delay in the development of systemic infection. From alkaline hydrolysates of the nucleic acid prepared from virus isolated from 8-azaguanine-treated 
plants, a compound was isolated which had the expected properties of 8-azaguanylic acid. This evidence together with analytical data showed that in tobacco mosaic virus from 14-day-old infections in 8-azaguanine-treated plants, about $3-4 \%$ of the guanine in the virus nucleic acid was replaced by 8 -azaguanine. This incorporation of 8 -azaguanine appeared to reduce the infectivity of the virus, also Bawden (1954) found that the inhibitors of plant virus increase include pyrimidine, purine analogues 2-thiouracil, and 8 -azaguanine inhibit virus multiplication by affecting some host-cell mechanism, Staehelin \& Gordon (1960) found that the inhibition of TMV formation and the incorporation of 5-fluorouracil into viral RNA occurs in Phlox drummondi as well as in the Turkish tobacco host. The inhibitory action of 5-fluorouracil on the formation of TMV in isolated leaf disks of Turkish tobacco plants is dependent on the time interval which has elapsed between infection and exposure to 5-fluorouracil, Fraser \& Whenham (1978) found that from their experiments on time of application; the methyl benzimidazol-2yl-carbamate inhibits tobacco mosaic virus ribonucleic acid synthesis indirectly, by maintaining the host "tobacco plants" in a state unsuitable for viral multiplication, another research for Gupta \& Roy (1981) found that foliar sprays of test plant with some purine and pyrimidine analogues at 500ppm an hour after inoculation of sunflower mosaic virus rendered 91.90-100\% virus incapable of initiating infection. Same results were obtained for human viruses on these types of chemical compounds; a series of pyrazinecarboxamide derivatives were found to inhibits the influenza viral RNA-dependent RNA polymerase by Furuta et al. (2009). Similarly, Fan et al. (2011) found in his study that the mechanism of action of novel thiourea containing chiral phosphonate on Tobacco mosaic virus was by inhibiting the polymerization process of TMV capsid protein in vitro, also Wang et al. (2018) found that pyrazolo $[3,4-d]$ pyrimidine derivatives containing a schiff base moiety had a strong antiviral activity against TMV because this moiety displayed strong binding capability to TMV capsid "coat" protein.

\section{Conclusion}

Finally, from this comprehensive study, two new synthetic compounds belonging to the fused heterocyclic pyrimidines with potent antiTNV and anti-TMV viruses activity have been identified; 1-(6-p-Tolyl-pyridazin-3-yl)-1,5dihydro-pyrazolo[3,4-d]-pyrimidine-4-one and 1,10-Dihydroindeno $\quad\left[1^{\prime}, 2^{`}: 4,5\right] \quad$ thieno[2,3-d] $[1,2,4]$ triazolo[4,3-a] pyrimidine-5-one. The compound named 1-(6-p-Tolyl-pyridazin-3yl)-1,5-dihydro-pyrazolo[3,4-d]-pyrimidine-4one was able to inactivate both virus directly (act as virus inactivator) while that named 1,10-Dihydroindeno $\quad\left[1^{\prime}, 22^{`}: 4,5\right] \quad$ thieno[2,3-d] $[1,2,4]$ triazolo[4,3-a]pyrimidine-5-one was able to inhibit viruses replication (act as virus inhibitor) without damaging or affecting the host cells of plant. A future goal will be concerned with the chemical modification in the structure "design" of these new antiviral compounds by changing or insertion of one or more functional groups to either the pyrimidine nucleus or its side chain to improve "increase" their inhibitory activity and make them able to target various stages in the plant viral life cycle which would avoid eliciting drug resistance.

\section{References}

Abdel-Megeid, F.M.E., Hassan, N.A., Mahran, M.A., Rashad, A.E. (1998) A one-step synthesis and antimicrobial activities of new substituted dihydro1,3,4-thiadiazoles. Sulfur Letters, 21(6), 269-284.

Afolabi, K.O., Iweriebor, B.C., Okoh, A.I., Obi, L.C. (2017) Global status of porcine circovirus type 2 and its associated diseases in sub-saharan Africa, Advances in Virology, 2017(10), 1-16.

Agrofoglio, L. A., Gillaizeau, I., Saito, Y. (2003) Synthesis of some novel hydrazono acyclic nucleoside analogues. Chemical Reviews, 103, 1875.

Alfarouk, Omar R., Barakat, A.B., Shoman, Sahar A., Ali, M.A., Rashad, A.E. (2013) Screening of some synthetic fused heterocyclic pyrimidines for antiavian influenza virus (H5N1) activity. Egyptian Academic Journal of Biological Sciences, 5(1), $25-$ 33.

Amoros, M., Lurton, E., Boustie, J., Girre, L. (1994) Comparison of the antiherpes simplex virus activities of propolis and 3-methyl-But-2Enyl cafferate. Journal of Natural Products, 57(5), 644647.

Armarego, W.L.F. (1967) In: "The Chemistry of Heterocyclic Compounds, Fused Pyrimidines, Part 
I: Quinazolines", Brown, D.J. (Ed.), Vol. 24/1, Interscience Publishers: New York - London Sydney.

Ashkin, A., Dziedzic, J.M. (1987) Optical trapping and manipulation of viruses and bacteria, Science, 235, 1517-1521.

Bawden, F.C. (1954) Inhibitors and Plant Viruses. Advances in Virus Research, 2, 31-57.

Borissensko, S., Schuster, G., Schmygla, W. (1985) Obtaining a high percentage of explants with negative serological reactions against viruses by combining potato meristem culture with phytoviral chemotherapy. Phytopathology Z, 114, 185-188.

Boualem, A., Dogimont, C., Bendahmane, A. (2016) The battle for survival between viruses and their host plants. Current Opinion in Virology, 17, 32-38.

Brown, J.K., Fauquet, C.M., Briddon, R.W., Zerbini, M.E., Moriones, Navas-Castillo, J., Adams, M.J., Carstens, E.B., Lefkowitz, E.J. (2012) The single stranded dna viruses, Geminiviridae. In: Virus Taxonomy-ninth Report of the International Committee on Taxonomy of Viruses, pp. 351-373.

Cerda, R., Avelino, J., Gary, C., Tixier, P., Lechevallier, E., Allinne, C. (2017) Primary and secondary yield losses caused by pests and diseases: Assessment and modeling in coffee. PloS One, 12, e0169133.

Dawson, W.O., Boyd, C. (1987) Modifications of nucleic acid precursors that inhibit plant virus multiplication. Phytopathology, 77(3), 477-480.

De Clercq, E. (2004) Nucleoside analogues exerting antiviral activity through a nonnucleoside mechanism. Nucleosides, Nucleotides, 23, 457-470.

Dijkstra, J., Van Rensen, J.J.S. (1968) Effect of 6-azauracil on infection with tobacco mosaic virus. Netherlands Journal of Plant Pathology, 74(6), 193-201.

Edwardson, J.R., Christie, R.G. (1997) "Viruses Infecting Peppers and other Solanaceous Crops". Vol. 1, pp. 320-336. University of Florida, Monograph 18-1, Gainesville.

El-Gazzar, A.B.A., Hafez, H.N., Abu-Hashem, A.A., Aly, A.S. (2009) Synthesis and antioxidant, antiinflammatory, and analgesic activity of novel polycyclic pyrimido[4,5-b]quinolines. Phosphorus, Sulfur and Silicon and the Related Elements, $\mathbf{1 8 4}$ (2), 379-405.

Fan, H., Song, B., Bhadury, P.S., Jin, L., Hu, D., Yang, S. (2011) Antiviral activity and mechanism of action of novel thiourea containing chiral phosphonate on Tobacco Mosaic virus. International Journal of Molecular Sciences, 12(7), 4522-35 .

Fraser, R.S.S., Whenham, R.J. (1978) Chemotherapy of plant virus disease with methyl benzimidazol2yl-carbamate: effects on plant growth and multiplication of tobacco mosaic virus. Physiological Plant Pathology, 13, 51-64.

Furuta, Y., Takahashi, K., Shiraki, K., Sakamoto, K., Morrey, J. (2009) T-705 (favipiravir) and related compounds: Novel broad-spectrum inhibitors of RNA viral infections. Antiviral Research, 82, 95102.

Fujiwara, N., Nakajima, T., Ueda, Y., Fujita, H.K., Awakami, H. (2008) Studies on heterocyclic compounds of medicinal interest. Bioorganic \& Medicinal Chemistry, 16(22), 9804-9816.

Gupta, K.C., Roy, A.N. (1981) Effect of purine and pyrimidine compounds on the infectivity of Sunflower Mosaic virus in vitro and in vivo. Proceedings of the Indian National Science Academy. Part B. Biological Sciences, 6, 912- 914.

Hegab, M.I., Hassan, N.A., Rashad, A.E., Fahmy, A.A., Abdel-Megeid, M.E. (2007) Synthesis, reactions, and antimicrobial activity of some fused thieno[2,3- $d]$ pyrimidine derivatives. Phosphorus, Sulfur, and Silicon, 182(7), 1535-1556.

Islam, W., Zaynab, M., Qasim, M., Wu, Z. (2017) Plantvirus interactions: Disease resistance in focus. Hosts Viruses, 4, 5-20.

Lister, J.H. (1971) In: "The Chemistry of Heterocyclic Compounds, Fused Pyrimidines, Part II: Purines", Brown, D.J. (Ed.), Vol. 24/2, Wiley-Interscience: New York-London-Sydney-Toronto.

Mohamed, S.F., Flefel, Eman M., Abd El-Galil, E.A., Abd El-Shafy, Dina N. (2010) Anti-HSV-1 activity and mechanism of action of some new synthesized substituted pyrimidine, thiopyrimidine and thiazolopyrimidine derivatives. European Journal of Medicinal Chemistry, 45, 1494-1501.

Egypt. J. Bot. 60, No.2 (2020) 
Matthews, R.E.F. (1953) Chemotherapy and Plant Viruses. Journal of General Microbiology, 8, 277288.

Mossman, T. (1983) Rapid colorimetric assay for cellular growth and survival: Application to proliferation and cytotoxicity assays. Journal of Immunological Methods, 65(1-2), 55-63.

Ralph, R.K., Wojcik, S.J. (1976) Inhibition of turnip yellow mosaic virus synthesis by pyrimidine analogues. Biochimica et Biophysica Acta, 444(1), 261-268.

Rashad, A.E., Ali, M.A. (2006) Synthesis and antiviral screening of some thieno[2,3-d] pyrimidine nucleosides. Nucleosides, Nucleotides, and Nucleic Acids, 25, 17-28.

Rashad, A.E., Heikal, O.A., El-Nezhawy, A.O.H., Abdel-Megeid, F.M.E. (2005) Synthesis and isomerization of thienotriazolopyrimidine and thienotetrazolopyrimidine derivatives with potential anti-inflammatory activity. Heteroatom Chemistry, 16(3), 226-234.

Rashad, A.E., Hegab, M.I., Abdel-Megeid, R.E., Micky, J.A., Abdel-Megeid, F.M.E. (2008) Synthesis and antiviral evaluation of some new pyrazole and fused pyrazolopyrimidine derivatives. Bioorganic \& Medicinal Chemistry, 16, 7102-7106.

Rashad, A.E., Shamroukh, A.H., Abdel-Megeid, R.E., Mostafa, A., El-Shesheny, R., Kandeil, A., Ali, M. A., Banert, K. (2010) Synthesis and screening of some novel fused thiophene and thienopyrimidine derivatives for anti-avian influenza virus (H5N1) activity. European Journal of Medicinal Chemistry, 45, 5251-5257.

Schuhmacher, A., Reichling, J., Schnitzler, P. (2003) Virucidal effect of peppermint oil on the enveloped viruses herpes simplex virus type 1 and type 2 in vitro. Phytomedicine, 6-7, 504-510.

Selvam, P., Narayanan, M., Markandavel, C., Robert, W., Wandersee, K., Donald, F. (2006) Antiinfluenza virus activities of 4-[(1,2-dihydro-2oxo- 3H-indol-3-ylidene)amino]- $N$-(4,6-dimethyl2-pyrimidin- 2-yl)benzenesulphonamide and its derivatives. Antiviral Chemistry \& Chemotherapy, 17, 269-274.

Shamroukh, A.H., Rashad, A.E., Sayed, H.H. (2005) Synthesis of some pyrazolo[3, 4]pyrimidine derivatives for biological evaluation. Phosphorus, Sulfur, and Silicon, 180, 2347-2360.

Smookler, M.M. (1971) Properties of inhibitors of plants virus infection occurring in leaves of species in chenopodiales. Annals of Applied Biology, 69, 157-168.

Staehelin, M., Gordon, M.P. (1960) Effects of halogenated pyrimidines on the growth of tobacco mosaic virus. Biochimica et Biophysica Acta, 38, 307-315.

Šutič, D.D., Ford, R.E., Tošič, M.T. (1999) "Handbook of Plant Virus Diseases", pp. 321-432. CRC Press, New York.

Velazhahan, R., Narayanasamy, P. (1991) Inhibition of tomato spotted wilt virus (TSWV) by plant extracts. Science and Culture, 57, 141-142.

Wang, Yan-Yan, Fang-Zhou, Xu, Yun-Ying, Zhu, Baoan, Song, Shunhong, Chen (2018) Pyrazolo[3,4- $d]$ pyrimidine derivatives containing a Schiff base moiety as potential antiviral agents. Bioorganic \& Medicinal Chemistry Letters, 28(17), 2979-2984.

Wenneng, Wu, Qin, Chen, Anqi, Tai, Guangqi, jiang, Guiping,Ouyang (2015) Synthesis and antiviral activity of 2-substituted methylthio-5-(4-amino2-methylpyrimidin-5-yl)-1,3,4-oxadiazole derivatives. Bioorganic \& Medicinal Chemistry Letters, 25(10), 2243-2246.

Yang, Y., Klessig, D.F. (1996) Isolation and characterization of a tobacco mosaic virusinducible myb- oncogene homolog from tobacco, Proceedings of the National Academy of Sciences, 93, 14972-14977.

Zhang, J., Zhan, B., Yao, X., Gao, Y., Shong, J. (1995) Antiviral activity of tannin from the pericarp of Punica granatum L. against genital herpes virus in vitro. Zhongguo Zhong Yao Za Zhi, 20(9), 556-558, 576. 


\section{فحص بعض المركبات المخلقة من المشتقات الحلقية للبيريميدينات كمضاد لقيروس تنكرز الاخان و فيروس تزرقش الدخان و آلية عملها}

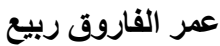

$$
\begin{aligned}
& \text { قسم الميكروبيولوجى - كلية العلوم - جامعة عين شمس - القاهرة - مصر. }
\end{aligned}
$$

تعتبر الفيروسات النباتية والتى تلقب "بسرطان النباتات" أحد أهم و أخطر الهشاكل التي تواجه العالم أجمع و هى المسؤلة وحدها عن تدمير ما يقرب من ثلاثين بالمئة من المحاصيل الاقتصادية الهامة حول العالم. و نظر الصعوبة السيطره على أغلب الفيروسات وذلك لأنها طفيل داخل خلوي إذ يعتمد

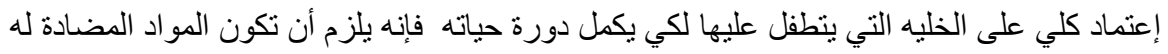
ذات نأثير فعال على الفيروس دون أن تئثر علي الخليه العائل. وقد أثثير الاهتمام للبيريميدينات ومشتقات الترايازول بسبب تتو عها في الأنثطة الحيوية خصوصا كمواد فعاله مضادة للفيروسات ومضادة للأورام ومضادة للبكتريا. في هذا البحث نم إختبار النشاط التثبيطي لثمانية مركبات كيميائية

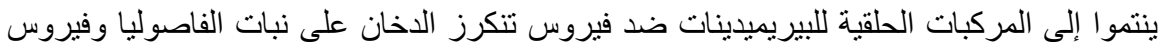

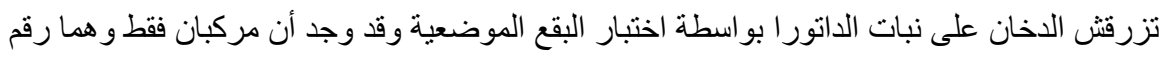
و احد ورقم ثمانية كانت لهما قوة تثبيطيه مرتفعه على كلا الفيروسين عند التركيز10 و20 مايكرو جرام /مل بينما الستة مركبات المتبقية كانت لهم قدره تثبيطية ضعيفة أو منعدمة على الفيروسين عند نفس التركيزات. وبعد دراسه لألية عمل كلا المركبين الفعالين قد تبين لنا الأتى: الدركب رقم واحد له له

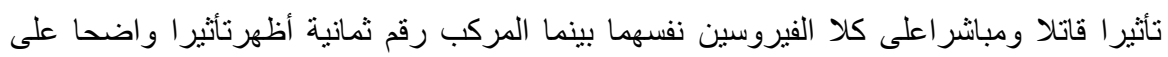

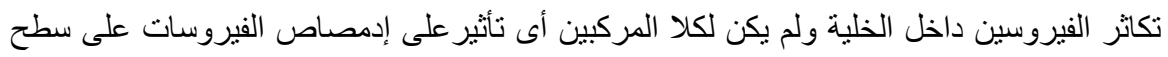

